\title{
EFEKTIFITAS PELAKSANAAN EKSEKUSI DENDA TILANG DI KABUPATEN PULANG PISAU
}

\author{
The Effectiveness Of The Implementation Of Fine Tilang Execution \\ In The District Of Pulang Pisau City
}

\section{Muhamad Yusuf Turyan IndahNurcahyanti}

Universitas Muhammadiyah Palangkaraya, Palangka Raya, Central Kalimantan, Indonesia

email:

yusuf.quratayun@gmail.com

\section{Kata Kunci: \\ Efektifitas \\ Pelaksanaan \\ Eksekusi}

Keywords:

Efectiveness

Implementation

Execution

\section{Accepted}

January 2018

\section{Published}

April 2018

\begin{abstract}
Abstrak
Penelitian ini bertujuan untuk mengetahui mekanisme pelaksanaan eksekusi denda uang tilang oleh Kejaksaan Negeri Pulang Pisau dalam perkara tindak pidana pelanggaran lalu lintas, serta untuk mengetahui hal-hal apakah yang menjadi kendala bagi Kejaksaan Negeri Pulang Pisau dalam menjalankan tugas atau peranannya sebagai eksekutor denda uang dalam perkara tindak pidana pelanggaran lalu-lintas, dan mengetahui tindakan yang dilakukan sebagai solusi dari permasalahan tersebut. Penelitian ini menggunakan metode penelitian kualitatif. Sumber data berasal dari pegawai Kejaksaan Negeri Pulang Pisau dan para pelanggar tilang, serta dokumendokumen yang mendukung penelitian ini. Teknik pengumpulan data dengan cara observasi, wawancara, dokumentasi serta triangulasi.

Hasil penelitian ini dapat diketahui efektivitas pelaksanaan eksekusi denda tilang di Kejaksaan Negeri Pulang Pisau telah menunjukkan hasil yang positif, hal ini ditunjukkan dengan jumlah perkara tilang yang yang telah dieksekusi memiliki presentase yang lebih besar dari perkara tilang yang masih menjadi tunggakan. Namun tunggakan tilang yang belum dapat diselesaikan tetap membutuhkan tindak lanjut penyelesaian, mengingat besarnya potensi penerimaan negara yang bisa didapat dari pembayaran denda tilang. Hambatan yang dihadapi Kejaksaan Negeri Pulang Pisau dalam melaksanakan eksekusi denda tilang ialah antara lain denda tilang yang tidak segera dibayarkan oleh para pelanggar tilang, karena pelanggar tilang yang bukan merupakan penduduk yang berasal dari Pulang Pisau melainkan hanya pengendara yang melewati daerah Pulang Pisau; Pelanggar beralasan jika faktor kesibukan membuatnya tidak sempat menghadiri persidangan; serta besarnya beban kerja yang diterima oleh pegawai membuat penanganan perkara tilang menjadi kurang efisien.
\end{abstract}




\section{PENDAHULUAN}

Meningkatnya volume kendaraan pribadi di jalan raya yang tidak disertai penambahan akses jalan raya yang memadai untuk menampung banyaknya kendaraan pada saat ini, memberikan dampak negatif bagi para pengguna jalan.Kemacetan dan angka kecelakaan yang tinggi merupakan salah satu bukti dari dampak negatif banyaknya kendaraan yang berlalu lalang di jalan raya. Banyaknya pengguna jalan juga memungkinkan terjadinya pelanggaran lalu lintas. Dengan kata lain, semakin banyaknya pengguna kendaraan bermotor, berdampak pada ketertiban dan pelanggaran dalam berlalu lintas. Ketentuan yang dimaksud lalu lintas dan angkutan jalan pada pasal I (nomor I) UU No. 22 Tahun 2009 adalah satu kesatuan sistem yang terdiri atas Lalu Lintas, Angkutan Jalan, Jaringan Lalu Lintas dan Angkutan Jalan, Prasarana Lalu Lintas dan Angkutan Jalan, Kendaraan, Pengemudi, Pengguna Jalan serta pengelolaannya.

Adanya aturan dalam berlalu lintas bertujuan agar terjaganya ketertiban dan kenyamanan dalam berlalu lintas bagi semua pengguna jalan. Situasi lalu lintas saat ini diwarnai dengan mobilitias masyarakat yang cukup tinggi, pertambahan kendaraan cukup pesat namun kurang diimbangi dengan penambahan sarana dan prasarana jalan. Masih rendahnya kesadaran hukum masyarakat dalam mematuhi peraturan lalu lintas adalah beberapa faktor yang mempengaruhi belum terwujudnya sistem perlalu lintasan yang aman, tertib dan lancar.

Banyaknya pelanggaran di bidang lalu-lintas merupakan akibat dari kurang disiplinnya masyarakat dalam budaya berlalu-lintas di jalan raya, terlebih jika ada penggunajalan yang kurang atau tidak memahami tentang peraturan lalu lintas yang harusnya ditaati. Adapun tindakan bagi para pelanggar lalu-lintas ini adalah pemberian sanksi berupa denda ataupun yang sering kita dengar dengan istilah tilang.

Eksekusi putusan perkara tilang dilakukan oleh pihak kejaksaan selaku eksekutor dari suatu tindak pidana.
Kejaksaan memiliki kewenangan dalam suatu tindak pidana antara lain sebagai penuntut umum, melaksanakan penetapan hakim, dan juga sebagai eksekutor. Eksekusi itu sendiri didasarkan atas putusan yang diberikan oleh pihak Pengadilan Negeri dan surat perintah yang ditujukan oleh Kepala Kejaksaan Negeri kepada Jaksa Penuntut Umum. Akan tetapi, pelaksanaan eksekusi tilang belum dapat dikatakan sepenuhya optimal. Hal ini didasarkan dari masih banyaknya berkas perkara tilang yang belum dieksekusi, yang berarti belum dibayarkannya denda tilang oleh pelanggar serta belum dikembalikannya barang bukti kepada para pelanggar tilang, yang akhirnya menjadi tunggakan dari Instansi Kejaksaan selaku eksekutor.

Di Kejaksaan Negeri Pulang Pisau, pada kurun waktu 2013 hingga 2016 saja terdapat 535 tunggakan perkara tilang yang belum dapat dieksekusi dan masih menjadi piutang, dan terhadap denda tilang yang sudah terjadi sebelumnya memerlukan tindak lanjut penyelesaian. Dalam pelaksanaannya, eksekusi denda tilang dilakukan oleh seorang staf yang juga merangkap sebagai petugas bang bukti, hal ini berarti besarnya beban pekerjaan yang diterima oleh seorang pegawai menunjukkan pembagian tugas yang kurang proporsional. Kejaksaanmenyelengarakan pelayanan publik salah satunya adalah dengan melaksanakan eksekusi tilang, dimana Kejaksaan melayani dan melakukan pengadministrasian kepada pelanggar tilang yang ingin mengambil barang bukti tilang dan denda tilang yang sebelumnya telah diputus oleh pengadilan.

Denda dan biaya perkara pelanggaran lalu lintas/tilang merupakan bagian dari Penerimaan Negara Bukan Pajak (PNPB) yang berasal dari penegakan hukum oleh Kejaksaan RI. Namun, perkembangan nilai denda tilang sebagai tunggakan piutang Kejaksaan RI setiap tahunnya terus meningkat dan terhadap denda tilang yang sudah terjadi sebelumnya memerlukan tindak lanjut penyelesaian. Apabila piutang denda tilang semakin berkurang, maka efektivitas dari pelaksanaan eksekusi 
tilang dapat dikatakan telah tercapai. Sebaliknya, jika piutang denda tilang masih tetap atau bahkan terus bertambah, maka efektivitas pelaksanaan eksekusi tersebut belum tercapai.

\section{METODOLOGI}

Penelitian ini menggunakan pendekatan penelitian kualitatif. Strategi yang digunakan dalam penelitian ini adalah strategi penelitian kualitatif interaktif. Strategi ini merupakan studi yang mendalam menggunakan teknik pengumpulan data langsung dari orang dalam lingkungan alamiahnya. Teknik pengumpulan data dalam penelitian ini berupa observasi, wawancara, dan dokumentasi.Instrumen penelitian ini adalah peneliti itu sendiri. Penelitian ini menggunakan model analisis interaktif. Data dalam penelitian ini diperoleh melalui pengamatan, dokumentasi serta wawancara secara langsung, maka analisis data yang peneliti gunakan adalah model interaktif baik dalam pengumpulan data, reduksi data, sampai pada penarikan kesimpulan.

\section{HASIL DAN PEMBAHASAN}

Efektivitas dalam suatu organisasi menunjukkan pada tingkat pencapaian tujuan atau sasaran telah sesuai dengan yang ditetapkan. Dalam hal ini Kejaksaan Negeri Pulang Pisau sebagai salah satu organisasi pemerintahan yang bergerak dibidang hukum memiliki tugas dan wewenang yang telah diatur dalam pasal 30 Undang-Undang Nomor 16 Tahun 2004 Tentang Kejaksaan Republik Indonesia, diantaranya ialah melakukan penuntutan, melaksanakan penetapan hakim dan putusan pengadilan yang telah memperoleh kekuatan hukum tetap, dan lain lain.

Untuk melihat apakah pelaksanaan eksekusi denda tilang di Kejaksaan Negeri Pulang Pisau telah efektif sesuai dengan tujuan yang direncanakan, penulis menggunakan Kriteria atau ukuran mengenai pencapaian tujuan efektif atau tidak, yang dikemukakan oleh S.P. Siagian (1978), diantaranya adalah ukuran atau kriteria pelaksanaan yang efektif dan efisien, dimana kriteria ini digunakan penulis karena kriteria inilah yang paling relevan dengan penelitian yang dilakukan.

Dari data yang telah didapatkan bahwa perkara pelanggaran lalu lintas / tilang yang diputus secara verstek di Kejaksaan Negeri Pulang Pisau selama periode tahun 2017 yakni sebesar 988 perkara, dari jumlah tersebut diketahui ada sebanyak 75I perkara, yang telah dieksekusi dan sisanya sebanyak 237 perkara masih menjadi piutang Kejaksaan Negeri Pulang Pisau sebagai perkara yang belum dapat dieksekusi. Dari data tersebut, dapat dikatakan bahwa efektivitas dari pelaksanaan eksekusi denda tilang di Kejaksaan Negeri Pulang Pisau telah tercapai, mengingat jumlah dari perkara yang diselesaikan memiliki presentase yang lebih besar dari perkara yang masih menjadi piutang.

Akan tetapi, denda tilang yang masih menjadi tunggakan tetaplah memerlukan tindak lanjut penyelesaian, sesuai dengan tugas dan peranan jaksa sebagai eksekutor dari suatu tindak pidana. Dari 237 perkara tilang yang belum dapat dieksekusi, jumlah denda yang masih menjadi piutang tersebut tetap akan menjadi tunggakan hingga pelanggar datang ke Kantor Kejaksaan Negeri Pulang Pisau untuk membayarkan denda tilang. Karenanya, dilakukan penagihan ataupun pemanggilan terhadap para pelanggar tilang.

Upaya-upaya yang dilakukan oleh pihak Kejaksaan Negeri Pulang Pisau untuk dapat mengeksekusi denda tilang secara lebih optimal, bertujuan untuk dapatmengurangi piutang denda tilang oleh Kejaksaan. Mengingat betapa nilai denda tilang yang cukup besar dapat menambah penerimaan negara yang bukan berasal dari pajak (PNBP). Dari data yang disajikan oleh Pusat Data, Statistik Kriminal, dan Teknologi Informasi Kejaksaan Agung dalam bulan November 2014, Kejaksaan seluruh Indonesia menyetorkan langsung ke kas negara hasil denda perkara tilang sebanyak Rp 7.209.748.939.7I2,- atau sebesar Rp 7,2 Trilyun, sementara penyetoran hasil 
denda bulan Oktober 2014 adalah sebesar Rp 9.963.020.245.7I0,- atau sebesar Rp 9,96 Trilyun. Data tersebut diatas menunjukkan besarnya jumlah penerimaan negara yang dapat diserap dari sektor denda hasil penindakan pelanggaran lalu lintas jalan, dimana hal tersebut harusnya menjadi penerimaan yang amat menguntungkan bagi negara apabila penyerapan hasil denda pelanggaran lalu lintas dapat dilakukan secara optimal.

Hambatan yang terjadi dalam menangani perkara pelanggaran lalu-lintas ini adalah mengenai denda tilang yang tidak segera dibayarkan oleh para pelanggar tilang. Hal ini mengakibatkan menumpuknya berkas perkara tilang yang telah diputus pengadilan namun belum dapat di eksekusi dan pada akhirnya menjadi piutang bagi Kejaksaan Negeri Pulang Pisau. Hal ini menyulitkan pihak Kejaksaan Negeri Pulang Pisau apabila pelanggar tidak kunjung datang dan membayarkan denda dan mengambil barang bukti yang disita dalam perkara tilang di Kantor Kejaksaan Negeri Pulang Pisau, maka tindakan yang dilakukan oleh kejaksaan adalah tetap melaporkan adanya berkas perkara tersebut dan menunggu sampai pelanggar datang untuk membayarnya. Hal semacam ini merupakan kewenangan serta merupakan tugas dari pihak Kejaksaan Negeri Pulang Pisau sebagai pihak eksekutor untuk menagih pembayaran denda tilang dan biaya perkara tersebut kepada pelanggar.

Dari permasalahan tersebut, berdasarkan Surat Jaksa Agung RI tentang Pedoman Penyelesaian dan Kebijakan Akuntansi atas Piutang Negara Denda dan Biaya Perkara Pelanggaran Lalu Lintas/Tilang Yang diputus verstek, Nomor B040/A/Cu.2/03/2013 Tanggal 06 Maret 2013, terhadap para pelanggar yang belum membayarkan denda tilang, pihak Kejaksaan melakukan upaya penagihan dengan mengumumkan ditempat umum. Selain itu, mengupayakan pemberian sanksi tambahan dengan membatalkan surat dan kelangkapan kendaraan bermotornya melalui kerjasama dengan Kepolisian dan Kantor SAMSAT.

Namun Pelanggar cenderung merasa bahwa membayar denda tilang bukanlah suatu kewajiban untuk segera diselesaikan dan dapat dilakukan kapan saja, dalam artian denda tilang dapat dibayarkan lama setelah diputus pengadilan, atau bahkan pelanggar membayarkan denda hanya saat memerlukan surat kendaraan bermotor yang disita saja. Ketidaktahuan para pelanggar tilang seperti ini pula yang pada akhirnya membuat denda tilang sulit terselesaikan. Disisi lain, mengenai permasalahan ini, pihak Kejaksaan Negeri Pulang Pisau sendiri pun tidak pernah melakukan sosialisasi ataupun upaya untuk memberikan penyuluhan terhadap masyarakat mengenai pembayaran denda tilang dan prosedurnya, mengingat tugas dan wewenang Kejaksaan dalam UU No. 16 Tahun 2004 tentang Kejaksaan R.I. sebagaimana ditentukan dalam Pasal 30 salah satunya ialah membantu peningkatan kesadaran hukum masyrakat.

Berdasarkan Surat Jaksa Agung No. B040/A/Cu.2/03/20I3 perihal Pedoman Penyelesaian dan Kebijakan Akuntansi Atas Piutang Negara Denda dan Biaya Perkara Lalu Lintas/Tilang yang Diputus verstek, bahwa terhadap pelanggar yang tidak membayar denda yang telah ditetapkan oleh Pengadilan dan tidak mengambil SIM atau STNK yang ditahan, akan dimasukkan ke dalam Daftar Pencarian Pelanggar (DPP) dan selain itu Kejaksaan melakukan upaya penagihan kepada para pelanggar dengan cara mengumumkan di tempat terbuka untuk umum di Kantor Pengadilan Negeri, Kantor Kejaksaan dan/atau Kantor SAMSAT. Jika pelanggar tidak melakukan pembayaran hukuman denda dan biaya perkara dalam jangka waktu 2 (dua) bulan setelah putusan Hakim, maka SIM yang bersangkutan dapat dibatalkan dan STNK dapat tidak diterbitkan untuk tahun berikutnya sebelum yang bersangkutan memenuhi kewajibannya. 
Dalam pelaksanaannya, dilakukan koordinasi dengan Polri disertai dengan menyampaikan surat resmi.

Dalam Peraturan Jaksa Agung Nomor : PER036/JA/I2/20II tanggal 19 September 20II Tetang Standar Operasional Prosedur Penanganan $\mathrm{Ti}$ dak Pidana Umum, mensyaratkan adanya petugas khusus, yaitu Petugas untuk kepentingan administrasi penanganan perkara; Petugas Barang Bukti; dan Pengawal Tahanan. Sedangkan pada seksi Tindak Pidana Umum Kejaksaan Negeri Pulang Pisau tedapat kekuragan staf tata usaha, dimana untuk petugas tilang yang juga merangkap sebagai petugas penyiap barang bukti, juga berperan sebagai staf administrasi pada bidang tidak pidana umum di Kejaksaan Negeri Pulang Pisau. Besarnya beban pekerjaan yang diemban seorang pegawai menjadi salah satu faktor mengapa upayaupaya eksekusi denda tilang belum dapat dilakukan secara optimal. Kurangnya personel membuat pembagian tugas pegawai pada bidang tindak pidana umum di Kejaksaan Negeri Pulang Pisau menjadi kurang proporsional.

\section{KESIMPULAN}

Efektivitas eksekusi tilang periode tahun 2017 di Kejaksaan Negri Pulang Pisau telah menunjukkan hasil yang positif, hal ini ditunjukkan dengan jumlah perkara tilang yang yang telah dieksekusi memiliki presentase yang lebih besar dari perkara tilang yang masih menjadi tunggakan. Namun tunggakan tilang yang belum dapat diselesaikan tetap membutuhkan tindak lanjut penyelesaian, mengingat besarnya potensi penerimaan negara yang bisa didapat dari pembayaran denda tilang apabila dapat dilaksanakan dan dioptimalkan semaksimal mungkin. Tidak adanya urgensi yang dirasakan masyarakat mengenai sanksi tilang yang dijatuhkan kepadanya, ditambah lagi dengan tidak dilakukannya pemanggilan atau penerangan hukum/sosialisasi oleh Kejaksaan Negeri Pulang Pisau membuat denda tilang belum juga dapat dieksekusi secara optimal. Hal ini merujuk pada kesimpulan bahwa Kejaksaan Negeri Pulang Pisau masih belum memandang permasalahan piutang denda tilang sebagai suatu kendala yang membutuhkan tindakan penyelesaian secara lebih lanjut.

Hambatan yang terjadi dalam menangani perkara pelanggaran lalu-lintas ini adalah mengenai denda tilang yang tidak segera dibayarkan oleh para pelanggar tilang, karena pelanggar tilang yang bukan merupakan penduduk yang berasal dari Pulang Pisau melainkan hanya pengendara yang melewati daerah Pulang Pisau. Selain itu, pelanggar beralasan jika faktor kesibukan membuatnya tidak sempat menghadiri persidangan. Terlebih lagi, beban kerja yang diterima oleh pegawai membuat penanganan perkara tilang menjadi kurang efisien.

\section{REFERENSI}

Agus, Erwan Purwanto dan Dyah Ratih Sulistyastuti. 2012. Implementasi Kebijakan Publik: Konsep dan Aplikasinya Di Indonesia. Yogyakarta: Gava Media.

Dwiyanto, Agus.2005. Mewujudkan Good Governance Melalui Pelayanan Publik. Yogyakarta : Pustaka Pelajar.

Handyaningrat, Soewarno. 2008. Pengantar Ilmu Administrasi dan Manajemen. Haji Masagung. Jakarta.

Juliantara, Dadang. 2005. Peningkatan Kapasitas Pemerintah daerah Dalam Pelayanan Publik. , Jakarta : Gramedia.

Kurniawan, Agung. 2005. Tranformasi Pelayanan Publik. Pembaruan. Yogyakarta.

Ndraha, Taliziduhu. 2005. Teori Budaya Organisasi. Jakarta : PT. Rineka Cipta.

Sondang, Siagian, P. 200I. Manajemen Sumber Daya Manusia. Jakarta : Bumi Aksara.

Tangkilisan, Nogi Hessel. 2005. Manajemen Publik. Jakarta : PT. Gramedia Widiasarana Indonesia. 


\section{Perundang-undangan}

Undang-Undang RI No. 16 Tahun 2004 tentang Kejaksaan R.I.

Undang-Undang Republik Indonesia Nomor 22 Tahun 2009 tentang Lalu Lintas dan Angkutan Jalan Pasal 9 Keppres Nomor 29 Tahun 1984 dan Surat Edaran Jaksa Agung RI Nomor SE009/JA/9/1983 tanggal 12 September 1983 tentang Tata Cara Penanganan Uang Denda dan Biaya Perkara

Peraturan Presiden RI Nomor 38 Tahun 2010 Tentang Organisasi dan Tata Kerja Kejaksaan RI

Peraturan Pemeritah No. 80 Tahun 2002 tentang Tata Cara Pemeriksaan Kendaraan Bermotor Di Jalan Raya dan Penindakan Pelanggaran Lalu Lintas dan Angkutan Jalan

Peraturan Jaksa Agung RI Nomor : 009-A/JA/0I/20II tentang Organisasi dan Tata Kerja Kejaksaan Republik Indonesia.

Keputusan Jaksa Agung Republik Indonesia Nomor: KEP-5 I8/A/J.A/II/20II tanggal I Nopember 201I Tentang Administrasi Perkara Tindak Pidana.

Surat Jaksa Agung RI tentang Pedoman Penyelesaian dan Kebijakan Akuntansi atas Piutang Negara Denda dan Biaya Perkara Pelanggaran Lalu Lintas/Tilang yang Diputus Verstek, Nomor B040/A/Cu.2/03/2013 Tanggal 06 Maret 2013. 